\title{
Biopreparations for plants produced with basidiomycetes
}

Tsivileva O.M. ${ }^{1}$, Perfileva A.I. ${ }^{2}$, Pavlova A.G. ${ }^{3}$

${ }^{1}$ Institute of Biochemistry and Physiology of Plants and Microorganisms, Russian Academy of Sciences, Saratov, Russia; ${ }^{2}$ Siberian Institute of Plant Physiology and Biochemistry, Russian Academy of Sciences, Siberian Branch, Irkutsk, Russia;

${ }^{3}$ Irkutsk State University, Irkutsk, Russia

E-mail: tsivileva@ibppm.ru

Key message. Potentialities of the mushroom-originating preparations for potato recovery are shown. The metal(II) containing composites based on the metabolites of basidiomycetes exhibits the effect of enhancing the potato resistivity to phytopathogen.

Keywords: potato; mushrooms; phytopathogenic bacteria; metals(II); biocomposites

The development of agents effective against bacteria and safe for plants, for agricultural recovery from the bacterial pathogens remains actual. The chemical pesticides action is ecologically unfavorable. For solving such problems, the application of natural substances seems advisable.

This study is aimed at revealing of viability and response reactions of potato plants in vitro in the presence of metal(II)containing composites manufactured with macromycetes' metabolites, potentially useful for developing the technology for recovery of plants.

The results gained in the course of research into the influence of metal(II)-containing composites made on the basis of extracellular metabolites of basidiomycetes Pleurotus ostreatus, Ganoderma lucidum, Grifola umbellata, Laetiporus sulphureus, on the viability and response reactions of potato plants in vitro allow us to conclude the following.

Metal-containing biocomposites based on G. lucidum possess the greatest antibiofilm-forming efficiency vs the potato ring-rot causative agent, bacterium Clavibacter michiganensis subsp. sepedonicus (Cms). Iron- and cobalt-containing biopreparations suppress the occurrence of $C m s$ biofilms by $40-50 \%$.

Cobalt-containing agent is characterized by the noticeable increase in root biomass of potato plants, that, taking into account the antibiofilm-forming effect vs $C m s$, could be prerequisite for advisability of cobalt compounds' application to manufacture the biocomposites from basidiomycetes.

Copper-containing preparation based on G. lucidum is characterized by the moderate bactericidal and bacteriostatic action, possesses the antibiofilm-forming efficiency against $\mathrm{Cms}$, does not exert negative impact in respect to any biometric parameter under question in potato plants, does not show any phytotoxic action with plants, and enhances the potato resistivity to $C m s$.

One of the aspects of further research into the biocomposites based on the mushroom's metabolites should be putting into practice the ecologically safe agents against the bacterial infection of potato, that is actual under the conditions of increasing phytopathogen's resistivity to chemically made pesticides.

\section{Биопрепараты для растений на основе базидиомицетов}

Цивилева О.М. ${ }^{l}$, Перфильева А.И. ${ }^{2}$, Павлова А.Г. ${ }^{3}$

${ }^{1}$ Институт биохимии и физиологии растений и микроорганизмов Российской академии наук, Саратов, Россия; ${ }^{2}$ Сибирский Институт физиологии и биохимии растений Сибирского отделения Российской академии наук, Иркутск, Россия;

${ }^{3}$ Иркутский государственный университет, Иркутск, Россия

Аннотация. Показана перспективность грибных препаратов для оздоровления картофеля. Содержащие металль((II) композиты, полученные на основе метаболитов базидиомицетов, обладали эффектом усиления устойчивости картофеля к фитопатогену. Ключевые слова: картофель; высиие грибы; фитопатогенные бактерии; металлы(II); биокомпозиты Остается актуальной разработка эффективных против бактерий и безопасных для растений субстанций для оздоровления от бактериальных фитопатогенов. Действие химических пестицидов сопряжено с экологическими рисками. К решению подобных задач целесообразно подходить с применением препаратов на основе природных соединений.

Цель исследования - выявление жизнеспособности и ответных реакций растений картофеля in vitro в присутствии содержащих металлы(II) композитов, полученных на основе метаболитов макромицетов, с перспективой создания технологии оздоровления сельскохозяйственных растений.

Результаты, полученные в ходе исследования влияния содержащих металлы(II) композитов, полученных на основе внеклеточных метаболитов базидиомицетов Pleurotus ostreatus, Ganoderma lucidum, Grifola umbellata, Laetiporus sulphureus, на жизнеспособность и ответные реакции растений картофеля in vitro, позволили сделать следующие выводы.

Металлсодержащие биокомпозиты на основе G. lucidum обладают наибольшей антибиопленкообразующей эффективностью против возбудителя кольцевой гнили картофеля, бактерии Clavibacter michiganensis subsp. sepedonicus (Cms). Fe- и Cо-содержащие биопрепараты подавляют образование биопленок Cms на 40-50\%.

Кобальт-содержащий агент характеризуется заметным увеличением биомассы корней растений картофеля, что, с учетом эффекта подавления образования биопленок $\mathrm{Cms}$, можно считать предпосылкой целесообразности применения соединений кобальта для получения биокомпозитов на основе базидиомицетов.

Медь-содержащий препарат на основе G. lucidum характеризуется умеренным бактерицидным и бактериостатическим действием, обладает антибиопленкообразующей эффективностью против $\mathrm{Cms}$, не оказывает негативного влияния ни на один из изученных биометрических параметров растений, не проявляет фитотоксического действия в отношении растений, усиливает устойчивость картофеля к Cms.

Одним из аспектов дальнейшего исследования биокомпозитов из метаболитов высших грибов должно стать введение в практику экологически безопасных средств против бактериального заражения картофеля, актуальное в условиях повышающейся устойчивости фитопатогенов к пестицидам химического происхождения. 